Chapter Title: Caryatid Unplugged: A Cabaret on Performing and Negotiating Belonging and Otherness in Exile

Chapter Author(s): Evi Stamatiou

Book Title: Performing Exile

Book Subtitle: Foreign Bodies

Book Editor(s): Judith Rudakoff

Published by: Intellect. (2017)

Stable URL: https://www.jstor.org/stable/j.ctv9hj90p.15

JSTOR is a not-for-profit service that helps scholars, researchers, and students discover, use, and build upon a wide range of content in a trusted digital archive. We use information technology and tools to increase productivity and facilitate new forms of scholarship. For more information about JSTOR, please contact support@jstor.org.

Your use of the JSTOR archive indicates your acceptance of the Terms \& Conditions of Use, available at https://about.jstor.org/terms 


\section{Chapter 10}

Caryatid Unplugged: A Cabaret on Performing and Negotiating Belonging and Otherness in Exile

Evi Stamatiou 
This content downloaded from 194.66.216.40 on Mon, 25 Mar 2019 13:43:31 UTC All use subject to https://about.jstor.org/terms 
$\mathrm{I}$ n August 2013, I created and performed a solo cabaret show titled Caryatid Unplugged ${ }^{1}$ at the Edinburgh Fringe Festival in Scotland. ${ }^{2}$ I devised the performance to explore and expose notions of belonging and Otherness in relation to two female bodies in exile: my own and the Caryatid's feminized body. I am a Greek expatriate artist who moved to the United Kingdom in 2010, at the beginning of the so-called Greek crisis. ${ }^{3}$ The Caryatid is the ancient Greek marble column that was forcibly removed from Athens during the Ottoman occupation, and now "belongs" to the British Museum. The performance presents a response to UK Prime Minister David Cameron's 2011 refusal to return the Parthenon Marbles, ${ }^{4}$ including the Caryatid, to Greece, ${ }^{5}$ and to his suggestion to the House of Commons Liaison Committee in 2012 that the government should control Greek citizens' right to enter and remain in the United Kingdom. ${ }^{6}$ Cameron's statements caused me to experience an intensified sense of exile, which I explored in Caryatid Unplugged. This chapter investigates how this identity was challenged and negotiated through my interaction with the audience.

\section{The Creation of the Exile Identity}

Caryatid Unplugged incorporated an autoethnographic journey, so it is necessary in reflecting upon it that I explore my basic assumptions about exile and identity. My sense of belonging and Otherness is affected by my relationship with particular "imagined communities," a term coined by Benedict Anderson. Of course, Cameron does not know every member of the British nation, but he imagines that they exist and identifies himself as one of them. Similarly, he does not know all Greek nationals, but he conceives of them as another imagined community, and addresses them as such. While Cameron did not address me directly in his remarks, I felt that he did so indirectly, because I identify with the Greek imagined community. I will expand the term "imagined communities" beyond the idea of national identity and interpret it to include other identities and imagined communities that are not merely national.

For example, Stuart Hall describes identity as

[...] the processes that constitute and continuously re-form the subject who has to act and speak in the social and cultural world. Identity is the meeting point, or the point of future, between, on the one hand, the ideological discourses which attempt to interpolate or speak to us as social subjects, and, on the other, the psychological or psychical processes which produce us as subjects which can be spoken. ${ }^{8}$ 
Identity is fluid and multiple, and depends on the speaker's linguistic resources and the social context in which they are speaking and acting. Before moving to the United Kingdom, I identified as, among other things, female, Greek, European, and cosmopolitan: these are the imagined communities to which I wished to belong.

The importance of constructing such multiple identities is illustrated by Bourdieu's notion of habitus: "a set of dispositions and orientations that do not simply 'regulate' [our] actions, but define just who and what [we] are." Cameron's statements in 2011 and 2012 made me realize that my European and cosmopolitan identities were no longer available to me. Cameron's statements openly contrasted the Greek identity with the European. ${ }^{10}$ By using the words "we" and "our" in phrases such as "we are not going to lose them [the marbles]"11 and "our country," ${ }^{2}$ he asserted his British identity and set up an adversarial relationship between the British and the Greeks. His remarks challenged my European identity as a Greek, and implied that my Greek identity did not bear the same symbolic capital and power ${ }^{13}$ as the national identities of other European countries. ${ }^{14}$ His statements not only prevented me from claiming my desired cosmopolitan identity, but further ascribed to me the identity of the unwanted economic immigrant. As Austin writes, "Language is performative because its speaking produces what it claims." ${ }^{15}$ Cameron's statements imposed on me the identity of the Other.

After 2012, my Greek identity was altered, which affected my belonging and imposed Otherness in relation to my imagined communities. I reflected on Cameron's 2011 statement that the Ancient Greek Marbles were "our" [British] Marbles. I identified with the feminized marble Caryatid that was held in the British Museum and not allowed to return to her homeland. This connection triggered my exile identity. Cameron's power to challenge and transform my identities caused me to begin to negotiate my belonging and Otherness in exile. I sought to explore this sense of exile in Caryatid Unplugged.

The narrative of the performance focuses on two women who meet in an immigration office in London. The first woman is Rita, a Greek economic immigrant who is about to be deported. The second is the Caryatid, who wants to go back to Greece, but is forbidden to do so by Cameron. By creating and performing these two characters (among others), I could perform my intensified dual-exile identity. The piece rehearses a hegemonic approach to modern Greek national identity, which is perceived as inseparable from its Ancient Greek past. Rita represents my nostalgia for the European imagined community, and the Caryatid represents my nostalgia for Ancient Greece. Margherita Laera writes that nostalgia for Ancient Greece is closely linked to myths about the origins of the Western identity. ${ }^{16}$ I realized that, although my Greek identity makes me Other, the shared nostalgia evident in Cameron's statements could provide fertile ground for exploring my new identity and enacting it in the cultural field.

\section{The Enacting of Identity in Caryatid Unplugged}

Caryatid Unplugged was constructed as four sections, with each culminating in a song, which enabled me to explore different dimensions of my identity. The first three songs 
parodied pre-existing material, and the last presented a medley of well-known songs. In the creation process, I explored a variety of contemporary theatre performance practices, and my aesthetic and stylistic choices for the performance were greatly influenced by Aristophanic comedy. I also used elements of parody, puppetry, physical comedy, clowning, documentary, and verbatim theatre throughout the performance.

In the role of Narrator, I directly addressed the audience at the start of the play. I portrayed eight other characters during the performance: John (an immigration officer), Rita (a Greek woman), the Caryatid (the feminized, anthropomorphized marble column), Lord Elgin (who brought the Caryatid to Britain in 1801), Salim (a male illegal immigrant from Pakistan who lives in Greece), ${ }^{17} \mathrm{XX}$ (a female illegal immigrant in Greece, probably Bulgarian or Chinese in origin, who is a victim of human trafficking), ${ }^{18}$ a translator (who translates the Caryatid's song from Greek to English), and Melina Mercouri (famous film actress, and the former Greek Minister of Culture). The unseen David Cameron character was performed by a male British actor, as a disembodied voice transmitted through the theatre sound system.

In the first part of the play, Rita, the Greek woman, appeals to John, the immigration officer, to prevent her deportation to Greece. Her negotiation with him climaxes in a performance of a parody of alternative British rock band Pulp's 1995 hit song "Common People." Listening to Britpop in Greece during my teens and early university years played an important role in the construction of my European identity. This music provided more than entertainment to me: it delivered a crucial means of understanding the English language and culture. As a child, I spent many hours in classes learning English, French, and Italian. By the time "Common People" was released, my ability to understand and speak European languages became a primary way of accessing the imagined community of Europe. My fluency in English enabled me to consider myself what Bourdieu calls a "legitimate speaker," ${ }^{19}$ and a member of the imagined European community.

"Common People" depicts a privileged Greek female student who wants to "live like common people." ${ }^{20}$ This character did not sound like a Greek stereotype to me: the student seemed real and European. In my parody of the song, Rita is also a privileged Greek female student who moves to the United Kingdom and romanticizes the "poor folk," like the girl in the original song. However, because of the economic crisis, she later becomes one of the "poor folk" herself. My parodic lyrics warn the audience:

Well, be careful what you wish for, my wishes all came true.

My daddy lost the supermarket.

Tax officers had to start somewhere, and they started there.

Then daddy said, "We've got no money,"

I just laughed and said, "Oh, daddy, you're so funny."

He said "No." There is no-one smiling in Greece.

You have to live like common people $[\ldots]^{21}$ 


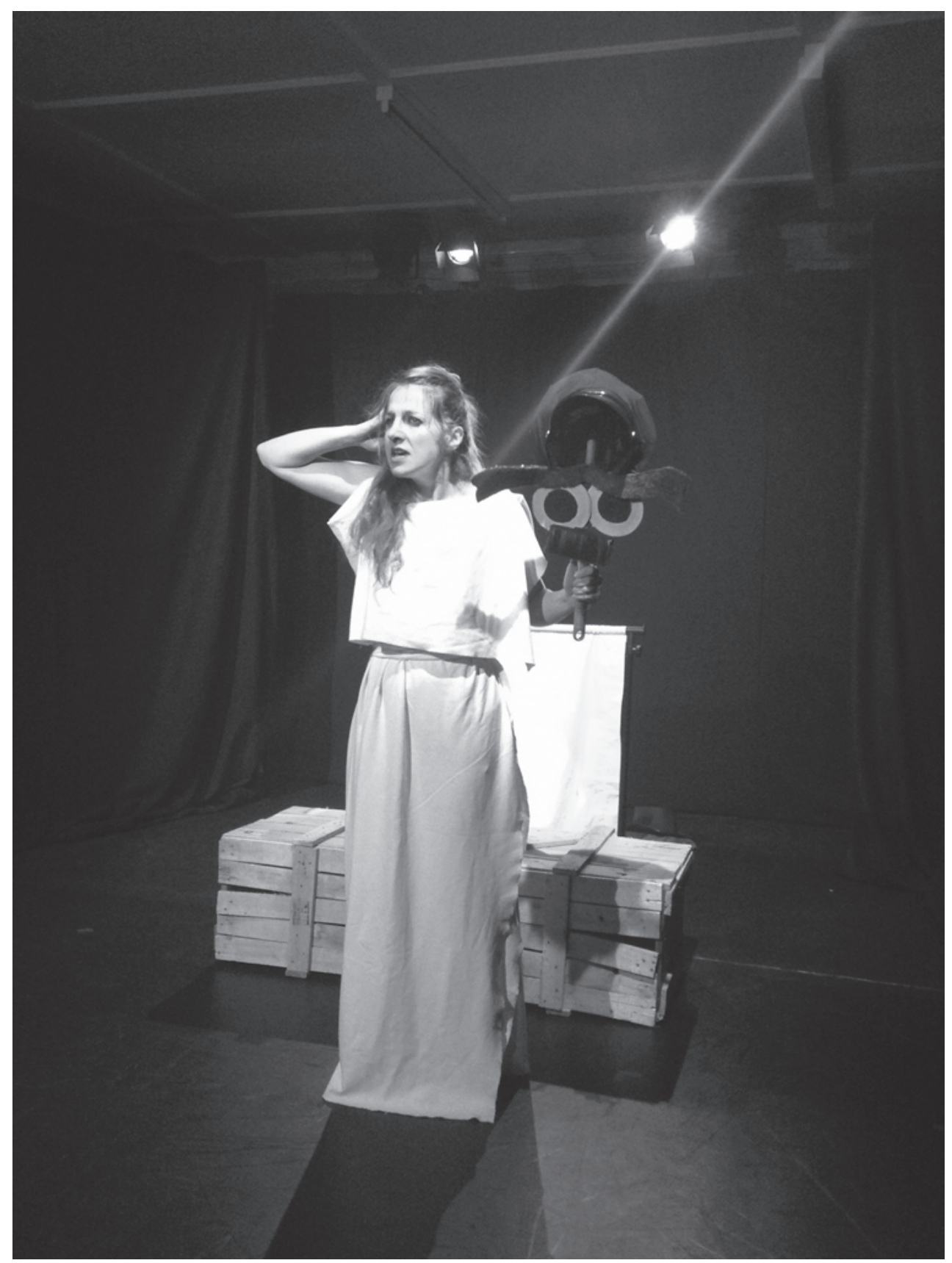

Figure 1: Evi Stamatiou in Caryatid Unplugged, Edinburgh Fringe Festival, 2013. The Caryatid asks the border officer John (broom puppet) to let her return to Greece. Photo credit: Katerina Valenti. 
After Rita's song, in the next section of the play, the Caryatid goes to the Immigration Office, delighted that all the Greeks residing in the United Kingdom will be sent back to Greece, but John informs her that she cannot return to her homeland because she belongs to the British Museum.

In a parody of the Broadway musical number "Big Spender" from Sweet Charity (1966), ${ }^{22}$ the Caryatid explains that she was seduced into going to England. In the original "Big Spender," the dance hall girls seduce their audience/customers to attain a "better life."23 In the parody of "Big Spender," the Caryatid tries to seduce Lord Elgin and persuade him to take her to the British Museum. The original lyrics of this song "The minute you walked in the joint," and "Hey, big spender! Spend a little time with me!"24 become, in my parody, "The minute you walked in the Acropolis," and "Hey, Lord Saviour! Take me to the British Museum!" 25 This song enabled me to explore my Greek identity through my Ancient Greek cultural heritage. The parodic song lyrics indicate an exchange of cultural consumption: Lord Elgin wants to consume Ancient Greece, and the Caryatid is willing to be consumed with the hope of acquiring the symbolic capital of the British Museum in return.

The notion of cosmopolitanism is highly problematic, as it is rooted in an elitist, Western concept that "celebrates the commodification of cultural difference." ${ }^{26}$ Gilbert and Lo identify three types of "New Cosmopolitanism": moral (rooted in the Kantian idea of a "universal community"); political (rooted in transnational governance and notions of cosmopolitan democracy); and cultural (rooted in an openness to different cultures and a desire to cross cultural boundaries). ${ }^{27}$ My cosmopolitan identity is rooted in cultural consumption and the ideal of an imagined universal community. It is related to the ideal of a cosmopolitan democracy, in which each culture has equal symbolic power.

In the performance, my Greek identity reaches for my Ancient Greek heritage in search of more symbolic power, but Elgin claims the Ancient Greek heritage as part of his own Western identity. As my Greek identity moves away from my Ancient Greek heritage, my exile identity is negotiated through the construction of a new Greek identity that feels dislocated from both Europe and Ancient Greece.

In the third part of the performance, Rita and the Caryatid blame each other for the Greek Crisis. Rita blames the Caryatid for treason/xenophilia:

RITA: I thought you loved foreigners.

CARYATID: What do you mean?

RITA: I mean the story with the Persians. You girls from Caryes betrayed Sparta! You took sides with the Persians back then in the 4th century BC. That is why you were doomed to hard labor. But now the barbarians are doomed to hard labor as well. And if they do not work as hard as we want them to, we kill them. ${ }^{28}$

Rita's revelation of how foreigners are treated in Greece allows for the Narrator's intervention to tell the story of Salim, a male immigrant from Pakistan who, when working in the 
strawberry fields in Manolada, Greece in 2008, was shot for asking for his wages. ${ }^{29}$ The story of Manolada and this example of immigration in modern Greece, allowed me to enact the moral perspective of my cosmopolitan identity:

NARRATOR: So by now, ladies and gentlemen, you must be thinking that there is nothing worse than being an illegal immigrant worker in Greece. Oh, yes, there is. Being a female illegal immigrant worker in Greece.

XX:

(applies red lipstick) I am XX (writes XX on her breasts), I belong to any age group, any ethnic group, any nationality. It is highly likely I am Bulgarian or Chinese. I do not have a name, not even a false name. I am not allowed to speak. I am not beautiful or clean. I am locked in a room with closed windows, somewhere hidden in the strawberry fields. I work day and night. The only way you could find out about my existence is if you read a Greek blog entitled "Where do the 8000 (writes "8000" on her back) immigrant workers of the strawberry fields fuck?" 30

Legal and illegal immigration in Greece has played a major part in the construction of my cosmopolitan identity. Immigration offers a different perspective on my cosmopolitan identity from that of cultural consumption, and is related more to the moral idea of a universal community. There were various numerals that figured prominently in Salim's story and in XX's story: I inscribed them all on my body in red lipstick, depicting the body as entirely reduced to a numeric value, however high or low its consumer value. Referring to this section of the play and its impact, critic Nick Awde, in his review for The Stage, wrote: "Under the slapstick, the finger stays firmly on our political pulse, and towards the end the message suddenly becomes shockingly clear when the spotlight turns on the exploitation at the heart of Europe's dark underbelly." ${ }^{11}$ This presentation of my exile identity, which is intrinsically linked to my female identity and the character XX, brought focus onto the vulnerability of the female body in exile.

After this section of the play, John telephones David Cameron in despair, and informs him of the Caryatid's desire to return to Greece. In a fantasy sequence, through the non-realistic use of a speaker-phone device, and the comic intervention of a translator, the Caryatid attempts to convince Cameron to let her go home, singing the traditional Greek song "Gianni Mou to Mantili Sou" ("My John, Your Handkerchief")..$^{32}$ In this song, the irreversible state of the stained handkerchief correlates to my irreversible traumatic experience, and reminds me once more of my exile identity.

This traditional song originates in my hometown, Epirus, and it is sung to the rhythm of the traditional Greek syrtos sta tria dance (which means "dragging in three steps"). Epirus is in the poorest area of Greece, and many people left there during the 1950s and 1960s to look for a better life abroad. In the song, Giannis (John) is revealed to be an exile, and his handkerchief is shown to have been stained by the dirt and grime of the hardship of his exilic life. He has tried to wash his handkerchief in five rivers, the song further explains, but 


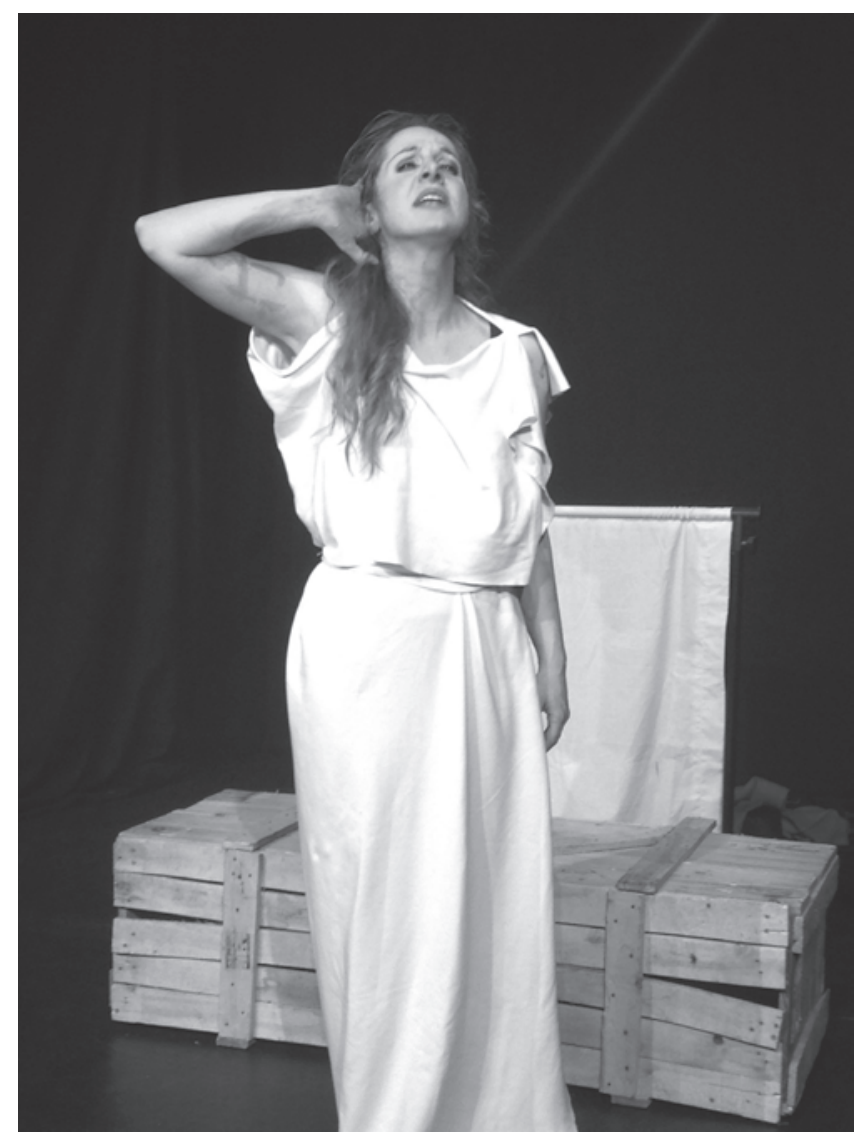

Figure 2: Evi Stamatiou in Caryatid Unplugged, Edinburgh Fringe Festival, 2013. The Caryatid sings "My John, Your Handkerchief" to persuade the British PM to permit her to return to Greece. Photo credit: Katerina Valenti.

nothing could cleanse the stain of exile. ${ }^{33}$ In my parody of the song, the emotional lyrics of the original verses are interrupted by a clumsy translator, who tries to explain to Cameron that the Caryatid longs to return to Greece. The comic interruption of the emotional song by the awkward translation further highlights the frustration of my exilic identity. This frustration caused by linguistic difference is closely related to my own occasional failures to communicate in a second language, owing to accent, grammar, and syntax mistakes, and the Othering that experience engenders. A particular difficulty demonstrated in the song is the translation of idioms, like the word "palikaraki":

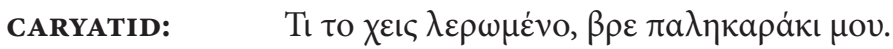

TRANSLATOR: Repeat please ... ${ }^{34}$ 


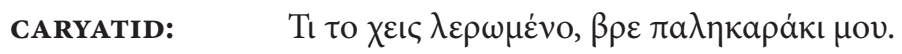

TRANSLATOR: How did it get that dirty, my (tries to find the appropriate word) ... Beautiful? (pauses) Amazing? Fantastic? One and only? Warrior?

This word cannot be translated, really ...

Huge penis maybe, John. ${ }^{35}$

In the fourth part of the show, Cameron will not change his mind, and will not be moved by the Caryatid's exile song. The former Greek Minister of Culture, Melina Mercouri, intervenes as a deus ex machina, and claims the Caryatid for Greece. She argues with Cameron, but ultimately loses. The Narrator's last words are:

A female goddess ex machina cannot find the perfect solution as if she were male. There has to be a choice which of the two will be fulfilled with the final verdict. Either they both go back to Greece or both stay in the UK. Please think and share your thoughts with us. If you believe you came up with a good solution, please write it down in the notebook just outside the theatre space. Maybe one day the Greek government will thank you for this. ${ }^{36}$

The performance concludes with a medley of Greek songs representing historic periods that played a major part in the construction of the Greek identity. During these periods, large numbers of Greek people emigrated, or Greek populations that lived in other countries for centuries were sent back to Greece as refugees. The medley included:

- Armand D’Angour's reconstruction of Ancient Greek music (2013);37

- the music of the Pontic Greeks $s^{38}$ (an ethnic group that had to return to Greece as refugees after World War I, early twentieth century);

- Vassilis Tsitsanis' "Cloudy Sunday" (composed during the German occupation in World War II, between 1940-44);

- "My John, Your Handkerchief" (1950, written for the economic immigrants to Germany in the 1950s and 1960s);

- Manos Hatzidakis' and Melina Mercouri's "Never on Sunday" (the only Greek song to have won an Academy Award, it was composed for the film Never on Sunday in which a nostalgic American scholar named Homer observes the degradation of Greek culture in the 1960s through his meeting with the Greek prostitute, Ilya);

- Mikis Theodorakis' "Zorba the Greek" (1964, based on Nikos Kazantzakis' novel Zorba the Greek, which refers to the Pontic Greeks' persecution at Caucasus, and to the life of Alexis Zorbas, who was a Romanian-born Greek);

- Dionysis Savvopoulos' "May the Dances Last" (1983, Savvopoulos was a politically active singer-songwriter who was briefly imprisoned during the Greek military dictatorship between 1967 and 1974. He wrote the song "May the Dances Last" two years after Greece joined the European Union in 1981). 
Through their lyrics and political association, the use of these songs to end the play expressed my Greek identity as a historical accumulation of emigration, immigration, population exchange, and refugee status.

\section{The Notebook as Public Sphere and Its Agonistic/Antagonistic Terms}

After the show, some audience members responded to my invitation to write in a notebook, which was situated on a pedestal outside the performance space, in the corridor leading to the venue's foyer.

The notebook functioned as a temporary theatrical public sphere. Jürgen Habermas writes that the bourgeois public sphere of the seventeenth to the twentieth centuries was the discursive, and not the physical, space of theatre, literature, and the arts. The public sphere was primarily apolitical, but offered a place in which non-specialists, or a combination of specialists and non-specialists, were able to discuss public issues. The constituent elements of the public sphere are freedom of access, freedom of speech, autonomy, and the equality of participants. These are the central preconditions of democracy. ${ }^{39}$

After my performance, the audience members were free to choose whether to write in the notebook, what to write, and whether to do so anonymously. The bourgeois public sphere is "the public of private individuals who join in debate of issues bearing on state authority" ${ }^{40}$ This requires that social integration be based on rational-critical discourse rather than domination. Such communication opens up space for a potential transformation in which "reason is advanced by debate itself." 41

The play's question of whether Rita and the Caryatid would return to Greece relates to state authority. However, I undermined the rational-critical discourse by posing a ridiculous dilemma to the audience: either both had to return to Greece, or both had to remain in the United Kingdom. The dilemma is ridiculous not only because it was suggested by neither Greece nor Cameron, but also because it contradicts the explicit desires of both parties. I identified Rita and the Caryatid as inseparable Others and asked the audience whether they thought Britain should allow their Otherness to remain in the United Kingdom. The ridiculousness of this assumption was an enactment reflecting my own ridiculous negotiation of identities according to which the undesired symbolic capital of the Greek female immigrant and the desired symbolic capital of the Caryatid as cultural commodity worked both with and against each other. The antagonistic relationship of my identities was an internalized replication of the antagonism that Cameron's statements triggered.

The dilemma of Rita's and the Caryatid's return to Greece formed a bridge between Cameron's statements and the audience. Cameron's statements were, as I have discussed, antagonistic. His use of the terms "we" and "our country" in discussing Greece implied that Greeks are "them." Chantal Mouffe writes that "democratic logic entails drawing a frontier between 'us' and 'them,' those who belong to the 'demos' and those outside it." ${ }^{2}$ When David 


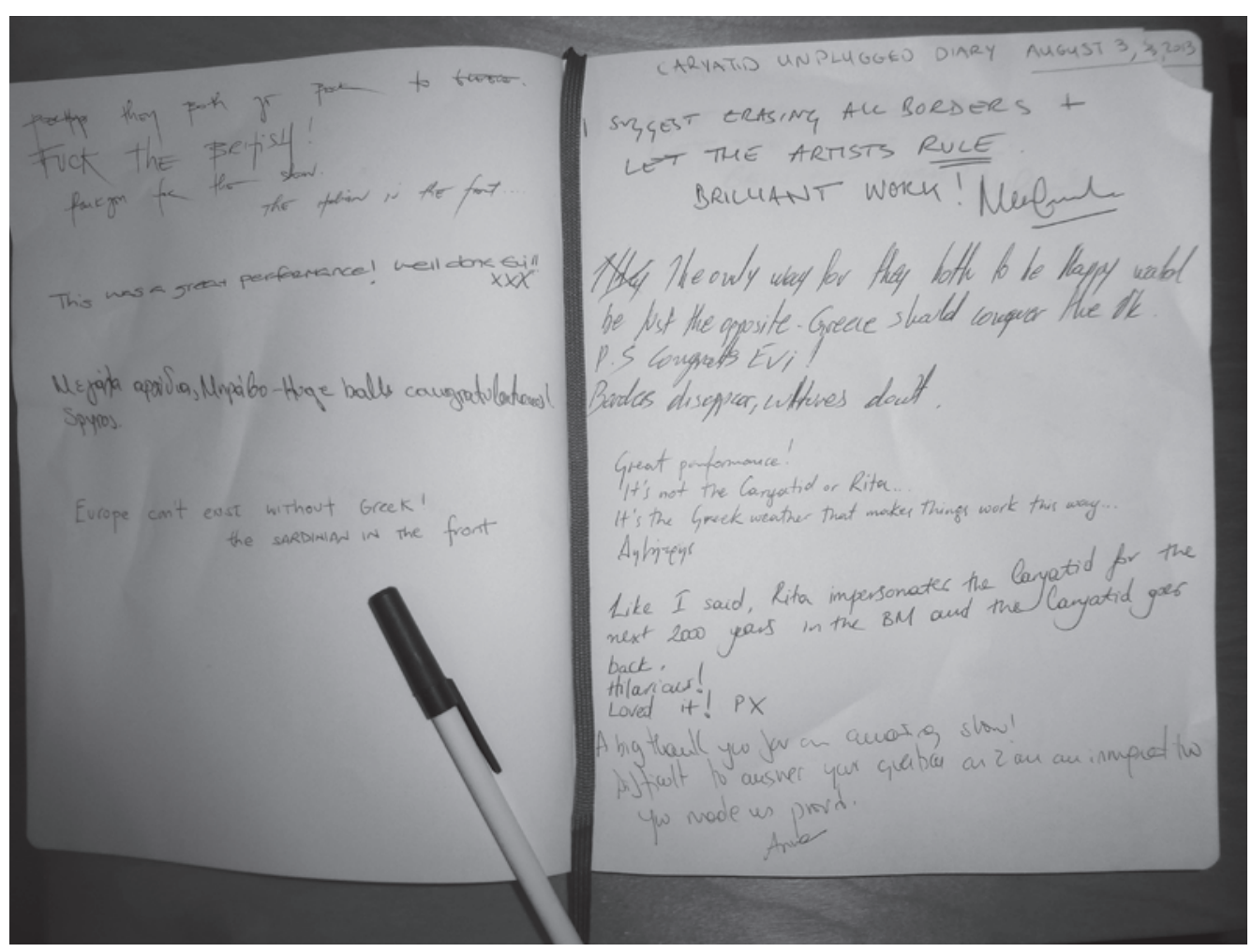

Figure 3: The notebook in which Caryatid Unplugged's audience responded to the question: "Should both Rita and the Caryatid stay in the UK, or should they both return to Greece?” August 3, 2013. Photo credit: Evi Stamatiou.

Cameron was asked in 2012 whether he intended to control the entry and residential status of Greek citizens in the United Kingdom, he replied: "I would be prepared to do whatever it takes to keep our country safe." ${ }^{3}$ The use of "our" implied the imagined British community and established an antagonistic us/them relationship with the Greek imagined community. Moreover, because at the time no other European people were targeted as "them," his statement implied that the frontier was solely between the European and the Greek imagined communities. Discussing Derrida, Mouffe writes that "the constitutive outside allows us to tackle the conditions of emergence of an antagonism." 44 Cameron's statement constructed frontiers for the Greek imagined communities, who became "them." In his statement about Greek immigration, it is not clear if Cameron considers the rest of the Europeans as "them" or "us." However, the us/them relation suggests antagonism, which can be perceived as friend/enemy distinction. Mouffe continues:

If collective identities can only be established on the mode of us/them it is clear that under certain conditions, they can always become transformed into antagonistic relations. A 
key task for democratic politics is therefore to create the conditions that would make it less likely for such a possibility to emerge. ${ }^{45}$

The exploration of the multiple identities and the ridiculousness of the utopian dilemma in Caryatid Unplugged aimed to challenge the friends/enemies duality that Cameron's statements suggested, and further expose the multiplicity and fluidity of identities based on notions of "us" and "them."

Chantal Mouffe suggests that the aim of democratic politics must be to transform antagonism into agonism without underplaying the antagonistic nature of democratic politics. She proposed the notion of "agonistic pluralism" as an alternative: "For agonistic pluralism the prime task of democratic politics is not to eliminate passions from the sphere of the public, in order to render a rational consensus possible, but to mobilize those passions towards democratic designs." ${ }^{46}$ Agonistic pluralism acknowledges the antagonistic nature of politics and emphasizes, rather than ignores, the role of emotions and passions. Cameron made his statements in the political space of the British Parliament, and they carried the emotions and passions of the social group that Cameron, I suggest, thought he represented.

Caryatid Unplugged sought to engage with politics in a theatrical context, and used the public sphere of the notebook to trigger audience responses about Otherness. I hoped that the notebook would allow agonistic pluralism to emerge. The notebook was open to any sort of discourse from the audience, and this endless possibility promised a discursive interaction that would allow agonistic pluralism.

\section{Negotiation of Identities and the Audience}

In the process of enacting my multiple and fluid identities, I did not attempt to predict or interpret the audience's reactions. Helen Freshwater, in Theatre \& Audience, writes that every audience member's interpretation of a performance differs according to their "own cultural reference points, political beliefs, sexual preferences, personal histories, and immediate preoccupations." ${ }^{37}$ She suggests that audience members' responses are based not only on their habitus and multiple, fluid identities, but on what they consider to be important at the moment that they are invited to respond. Freshwater's theory suggests that it would be difficult to make any assumptions about audience members' reactions to my invitation to write in the notebook. A question that this theory does not consider is why the majority of audience members decided not to respond at all. In any case, I am going to focus on the documented reaction of the minority of audience members who did leave written comments.

By the end of the run of twenty-three performances at the Edinburgh Fringe Festival between August 2 and 26, 2013, forty-two people had written in the notebook (out of a total audience of 297). Ten of the responses were from personal friends, who focused on the show and how I performed, and referred less to the political dimension. I analyzed the remaining 
thirty-two audience responses, focusing on how they commented on, and offered space for, a negotiation of my enacted identities.

Caryatid Unplugged was a political artistic project and as such, my methodological approach has been flexible. As I am neither a sociologist nor a statistician, I did not use the type of rigid methodology that they would apply. I aimed to generate critical responses from the audience, and then critically reflect on these responses from the perspective of the artist exploring their position of belonging and Otherness. I treated the notebook both as evidence of the audience's response to my performance, and as a set of performances in the temporary public sphere that I had created. Analyzing the responses through a personal filter enabled me to explore whether and how I was given permission to adopt specific identities and belong to particular imagined communities. In my analysis, I considered any use of words that would indicate an antagonism - like the duality us/them - and also the symbolic capital attributed to nationalities, judging from the context in which they were mentioned.

I will reflect on the negotiation of my belonging and Otherness through my European, Greek, exile, and cosmopolitan identities.

Two audience responses seemed to ally with my European identity:

A: $\quad$ Perhaps they both go back to Greece. FUCK THE BRITISH! Thank you for the show. THE ITALIAN in the front ...

B: $\quad$ EUROPE CAN'T EXIST WITHOUT GREEK! THE SARDINIAN IN THE FRONT.

B explicitly granted me membership in the European imagined community with the phrase "Europe can't exist without Greek!" The words "Greek" and "Europe" are used in the same sentence, which suggests that the two identities are inseparable. In A's response, the words "Greece" and "British" are in two separate sentences, which implies an antagonistic us/them relationship. A seems to attribute more symbolic capital to the Greek than to the British identity. Moreover, $\mathbf{A}$ and $\mathbf{B}$ show that they are allowing me to adopt a European identity by stating their own national identities, Italian and Sardinian. Their identities are also part of the European imagined community, but had not been challenged or questioned by Cameron. The fact that these two members of the European imagined community attributed more symbolic capital to the Greek identity than to the British reinforced my European identity.

$\mathbf{A}$ and $\mathbf{B}$ were the only audience members who revealed their national or local identities. The other respondents self-identified by only their names, although they often suggested a national identity. Although the text of Caryatid Unplugged implies the various characters' nationalities, I did not often directly use the terms "the Greeks" or "the British." However, I did use the term "the Italians" in the play at the point in the action where the Caryatid suspects that Lord Elgin is an enemy of the Acropolis:

$[\ldots]$ or maybe you are a bloody Italian trying to seduce me. Are you? Because there have been some Italians passing by this place [...]. Seducing, looting, making the best out of you, and in the end bombing you and abandoning you [...] Romans, Luisieri, Morosini, Mussolini, Pasolini, and others $[\ldots]^{48}$ 
Here, the Caryatid refers to historic Italian figures who had bombed the Acropolis. The stereotypical Italian male identity that is represented in the script seems to have been encoded by $\mathbf{A}$ and $\mathbf{B}$, and reproduced in their responses in the notebook. This is suggestive of a reciprocal relationship of identity negotiation during and after the performance.

Another example of audience members encoding an enacted identity can be seen in the inscriptions from audience members $\mathbf{C}, \mathbf{D}$, and $\mathbf{E}$ :

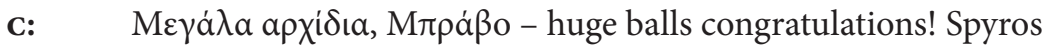

D: $\quad A v \delta \varepsilon v \varepsilon \dot{\chi} \chi \varepsilon ı \varsigma ~ เ \sigma \tau o \rho i ́ \alpha a \pi \lambda \dot{\alpha} \kappa \lambda \dot{\varepsilon} \beta \varepsilon ı \varsigma \mu$ ía. If you don't have history, you steal one.

E: Efharisto! ${ }^{49}$ Story very well told. Is "hypocrisy" a Greek word?? Kalispera, ${ }^{50}$ Steve and Sara

Audience members $\mathbf{C}$ and $\mathbf{D}$ are Greek speakers. They reproduced my use of the Greek language in Caryatid Unplugged, and wrote in the Greek alphabet, both of which created a shared temporary linguistic habitus. ${ }^{51}$ The only Greek language spoken in the script are the lyrics to the traditional Greek song "My John, Your Handkerchief," 52 discussed above, in which the song is repeatedly interrupted by the translator, who translates from Greek to English so Cameron can understand the Caryatid's feelings about her exile. The translation of the song in performance indicates that my Greek identity is intrinsically linked to my exile identity. $\mathbf{C}$ and $\mathbf{D}$ allowed me to claim this Greek/ exile identity.

E, who does not seem to be a native Greek speaker, uses English characters for Greek words without providing a translation because they know that I speak Greek. The dual Greek/exile identity is again indicated, but in a different way than in the examples of $\mathbf{c}$ and $\mathbf{D}$. On one hand, $\mathbf{C}$ and $\mathbf{D}$, who seem to be native Greek speakers, accept me as part of the Greek/exile imagined community. On the other hand, E's question "Is 'hypocrisy' a Greek word??" indicates that they think that I am legitimately a Greek speaker and that they are not. They thereby acknowledge the us/them duality and therefore my Greek identity and Otherness. E seems to try to counter my Otherness with a sense of belonging by reversing the translation device that I used in the song, but the group to which $\mathbf{E}$ offers me membership is not clearly defined. Another interesting element of E's response is the use of the double question mark, which invites an interpretation other than the literal: they ask if "hypocrisy" is a Greek word, but they are actually denouncing Cameron (or UK citizens in general) as hypocrites. In this case, I might consider that $\mathbf{E}$ is contributing to the rise of the symbolic capital of my Otherness, by undermining Cameron' symbolic capital. The speech enactment of such a rise of my symbolic capital offers me a sense of belonging.

For F, my identity as the Other is clearly an identity of belonging, because I am offered membership to an imagined community of immigrants:

F: $\quad$ A big thank you for an amazing show!!! Difficult to answer your question as I am an immigrant too. You made us proud!!! Anna 
G, $\mathbf{H}$, and I use the words "we" and "they," signifying an us/them duality, and reinforcing my Otherness:

G: $\quad$ Wish we could all appreciate how relaxed we are. Great performance! Jude X

H: Thank you for your great performance. They should go back to their homeland! Anne and Craig Wallace

I: $\quad$ We need someone like you in the UK!!! XXX

H separates me from the characters of the Caryatid and Rita. However, there is no invitation for me to belong, but only an indication of Caryatid's and Rita's Otherness. I's response was entered in the notebook straight after H's response. In isolation, $\mathbf{H}$ 's response could be seen as antagonistic, which perhaps caused $\mathbf{I}$ to intervene to contradict or better explain that entry. Although I's response initially seems like an invitation to belong, its we/you duality offers the position of belonging to the British imagined community as the Other. H's appreciation of me as a theatre-maker relates to my "aesthetic and consumer cosmopolitan identity." ${ }^{3}$ However, I am not the consumer, but the cultural commodity.

The negotiation of a cosmopolitan identity was evident in the comments in which there was no suggestion of the antagonistic we/them duality relating to national identity. Two examples of that kind are:

\section{J: I SUGGEST ERASING ALL BORDERS + LET THE ARTISTS RULE. BRILLIANT WORK! - MICHAEL \\ K: $\quad$ Solution? Blow up the Acropolis AND the British Museum?? PAV}

The temporary public sphere of the notebook, which included the audience's responses to my performed question about whether Rita and the Caryatid should return to Greece or not, allowed me to negotiate the identities that I embodied in Caryatid Unplugged with the audience. The identities were fluidly connected in the performance, and they seemed to be similarly interconnected in the notebook.

\section{Conclusion}

The Edinburgh Fringe Festival offered a unique opportunity to try out a hegemonic approach to the construction of the new Greek identity in an international environment. In my interaction with the audience, I created a binary opposition of an exile and a cosmopolitan identity. A cosmopolitan audience would consume me as a cultural commodity, and depending on how the audience identified themselves in relation to this binary, my exile identity would fluidly move.

My initial expectations were that audience responses would reveal dominant assumptions about their recently reconstructed notions of belonging and Otherness of the Greek 
imagined community in relation to the European and cosmopolitan one. I expected that this would be primarily negotiated through audience assumptions about identity, determined solely by their habitus, and impervious to any influence from the performance. I unexpectedly found that the negotiation of my identities was determined by how the assumptions about identity that I presented on stage were adopted and reproduced in the audience members' responses in the notebook I provided. This observation calls into question how free audiences are when responding to an invitation to interact with a theatremaker. The audience's assimilation of my unconscious orientation undermined my aim to create an agonistic pluralism, because the negotiation was framed and determined by the words that I chose and by my hidden presumptions. I recognize that it is difficult for a responder in a theatrical context to transcend a given language and its cultural connotations.

It could be suggested that the audience's reproduction of my presumptions demonstrates opportunities for agency within Caryatid Unplugged, given that I was able to frame, navigate, and extend the discourse. However, the audience's actions were not conscious, and unconscious actions are not necessarily performed freely. This indicates not only that I limited the audience's agency in responding, but also that my unconscious bias limited my own agency in negotiating my identity following analysis of the audience response.

Nevertheless, my agency was expanded by the opportunity to explore my own voice. According to Bakhtin, the individual's speech, or writing at the point of utterance, always springs from previous utterances (from others, from previous contexts), and are orientated towards some future response. Bakhtin describes it as "laden with the language of others, from previous contexts." ${ }^{44}$ Like Bourdieu's concept of habitus, this indicates that the individual has unconscious bias.

The temporary public sphere of the notebook enabled me to see my unconscious dispositions and to understand the bias that burdens the theatre-maker's voice. Caryatid Unplugged aimed to generate an audience response that might resemble a conscious, independent debate: instead, it functioned as a reflective mirror in which I could see myself. I concluded that I was indeed a cultural commodity in exile, enacting the dispositions of my habitus on shifting terrain determined by my own bias. But for the first time since becoming a theatre-maker, I was a cultural commodity that recognized her habitus, and therefore a cultural commodity with agency.

\section{Notes}

1 The term "unplugged" was chosen for two reasons. The main reason related to the relevance of the term to acoustic music. The composer Andreas Papapetrou composed special arrangements of the songs "Common People" and "Big Spender." The new arrangements were for acoustic piano. "Unplugged" was further used in its metaphorical sense. It aimed to indicate the dislocation of the marble column Caryatid from the porch of the Ancient temple Erechtheion, which is situated on the Acropolis in Athens. The metaphor aimed to highlight the loss of the Caryatid's functional purpose, which was to support the roof of Erechtheion's porch. 
2 As stated on the festival's website (to view full site, go to https://www.edfringe.com/, accessed April 12, 2016), the Edinburgh Festival Fringe is the largest arts festival in the world, counting (in 2015) 50,459 performances of 3,314 shows in 313 venues. The festival attracts both national and international performers and audiences. The Edinburgh Festival Fringe is part of Edinburgh's August Festivals, which is an umbrella term used to describe the three festivals that take place during that time: The Edinburgh International Festival (EIF), Edinburgh Festival Fringe (in which Caryatid Unplugged participated), and Edinburgh International Book Festival. EIF was launched after the Second World War with the aim of being an "enactment of a European communion" (The term was created by George Steiner in Jen Harvie, "Cultural effects of the Edinburgh International Festival: Elitism, Identities, Industries," in Contemporary Theatre Review 13, no. 4 [2003]: 14). The rise of the Edinburgh Fringe was a response to EIF's exclusivity of both artists and audiences. Jen Harvie in "Cultural Effects of the Edinburgh International Festival" analyzes the aims and objectives of EIF. Harvie observes that "the Festival reproduces this elitism, reinforcing and propagating its imbalances of cultural power and its anti-democratic effects" (Harvie, 13), and she further suggests that this elitism may not have "produced" the Edinburgh Fringe but definitely "provoked" it (Ibid., 14).

3 Manos Matsaganis writes in The Greek Crisis: Social Impact and Policy Responses (Berlin: Friedrich-Elbert-Stiftung, Department of Western Europe/North America, 2013), that the Greek debt crisis started in late 2009, and that by the end of 2013 the relative living standards in the country had fallen back by 34.3 percent below average living standards in Western Europe. By November 2013 (the year of performance of Caryatid Unplugged) Greece resembled the country as it had been in the 1960s (Matsaganis, 1). Unemployment reached 27.5 percent (Ibid., 6), which was a result of many Greek businesses going bankrupt. By 2012, 41 percent of unemployed workers were in relative poverty, and heavier taxation and salary deflation plunged even more below the poverty line (Ibid., 12). As a result, many Greeks emigrated to Western European countries like Germany and the United Kingdom. To view full article, go to http://library.fes.de/pdf-files/id/10314.pdf, accessed April 12, 2016.

4 On the British Museum's website, it is stated that the Parthenon Marbles were created about 2500 years ago in the Acropolis in Ancient Athens. They are marble panels and sculptures, and were structural elements of the Parthenon, which was an Ancient Temple of the goddess Athena. The Caryatid is a marble column depicting a female figure, which was part of the temple Erechtheion next to the Parthenon. The Parthenon marbles are also known as The Elgin Marbles, named after Lord Elgin, who transferred them from the Acropolis to the United Kingdom 200 years ago, during the Ottoman occupation. To view full page about the Caryatid, go to http://www.britishmuseum.org/research/ collection_online/collection_object_details.aspx?objectId=459389\&partId=1, accessed April 11, 2016. To view full page about the Parthenon Sculptures, go to http://www. britishmuseum.org/about_us/news_and_press/statements/parthenon_sculptures.aspx, accessed April 11, 2016.

5 Mulholland reports that the Liberal Democrat MP Andrew George said to Cameron: "Whilst of course we should not be making a unilateral contribution to the Greek bailout, does the 
prime minister not agree that we have something which would help regenerate the Greek economy and put right a 200-year wrong - and that is to give the marbles back?" Cameron replied that he had no intention of allowing Britain to "lose its marbles." He told MPs: "I'm afraid I don't agree... the short answer is that we're not going to lose them." Hélène Mulholland, "David Cameron Rejects Call to Return Parthenon Marbles to Greece," The Guardian, June 22, 2011. To view full article, go to http://www.theguardian.com/politics/2011/jun/22/ cameron-rejects-return-parthenon-marbles-greece, accessed February 15, 2016.

6 Watts reports that Cameron said that in the scenario of a Greek exit from the Euro zone, Britain was prepared to take measures to avoid a major influx of Greek citizens: "I would be prepared to do whatever it takes to keep our country safe, to keep our banking system strong, to keep our economy robust. At the end of the day, as prime minister, that is your first and foremost duty." Nicholas Watts, "David Cameron 'Prepared to Halt Immigration of Greeks into UK," The Guardian, July 3, 2012. To view full article, go to http://www.theguardian. com/uk/2012/jul/03/david-cameron-immigration-greece-uk/, accessed February 15, 2016.

7 Benedict Anderson, Imagined Communities: Reflections on the Origin and Spread of Nationalism (London and New York: Verso, 2006), 5. Anderson defines the nation as "an imagined political community - and imagined as both inherently limited and sovereign."

8 Stuart Hall, "Fantasy, Identity, Politics," in Cultural Remix: Theories of Politics and the Popular, ed. Erica Carter and James Donald (London: Lawrence \& Wishart, 1995), 65.

9 James Bohman, "Practical Reason and Cultural Constraint: Agency in Bourdieu's Theory of Practice," in Bourdieu: A Critical Reader, ed. Richard Shusterman (Oxford and Malden: Blackwell Publishers, 1999), 130.

10 Hannes Swoboda addressed the discrimination within a meeting in the European Parliament. To view video, go to https://www.youtube.com/watch?v=9X_HavzuY3o, UK Europe News, “David Cameron Cannot Halt Immigration of Greeks," YouTube video, 1:29, posted by UK Europe News, July 4, 2012, accessed April 9, 2016.

11 Mulholland, "David Cameron Rejects Call to Return Parthenon Marbles to Greece."

12 Watts, "David Cameron, 'Prepared to Halt Immigration of Greeks into UK."

13 According to Bourdieu's theory, all human action is driven by the desire to accumulate all forms of capital - economic, cultural, social, and symbolic - which inevitably creates conflict and power dynamics. Those power dynamics are later separated from the interests of capital accumulation and therefore pass unrecognized by other social groups. Such mystified symbolic power is the foundation of the dominant social classes. Zander Navarro, 'In Search of a Cultural Interpretation of Power: The Contribution of Pierre Bourdieu,' IDS Bulletin 37, no. 6 (2006): 19.

14 Pierre Bourdieu, Language and Symbolic Power (Cambridge: Polity Press in association with Blackwell, 1991), 95.

15 John Langshaw Austin, How to Do Things with Words, 2nd ed. (Oxford: Clarendon Press, 1975), 5.

16 Margherita Laera, Reaching Athens: Community, Democracy and Other Mythologies in Adaptations of Greek Tragedy (London: Peter Lang, 2013), 1.

17 Salim is a historical figure, an immigrant who is profiled in Fragisca Megaloudis' and Stelios Papardelas' article "Life in 'Cretan Manolada': Contemporary Slaves." Salim is the witness 
who describes the conditions of his own forced labour in the greenhouses of Crete, which were very similar to the conditions of forced labour in Manolada. The shooting of immigrant workers in Manolada by their employers triggered further interest and investigations around their forced labour. Fragisca Megaloudis and Stelios Papardelas, "Life in 'Cretan

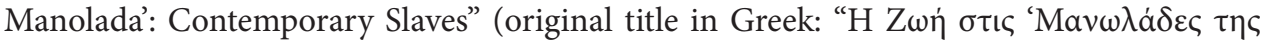

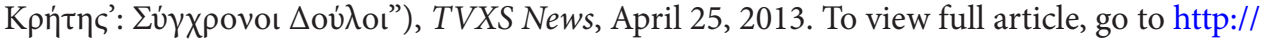

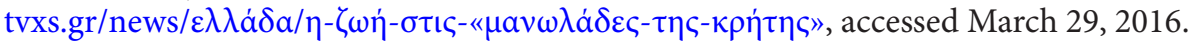

$18 \mathrm{XX}$ is a fictional character who represents a male immigrant's testimony about women forced into sex labour in the area of Manolada. This testimony appeared on the Omnia TV website in an article titled "Where Do the 8000 Refugees of \#manolada Fuck?" (original in

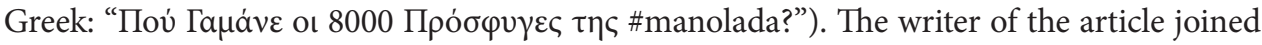
a protest following the Manolada shooting and he asked a Bangladeshi immigrant worker: "Hey, friend, where do you fuck around here, are there any women that you pay to get laid?"

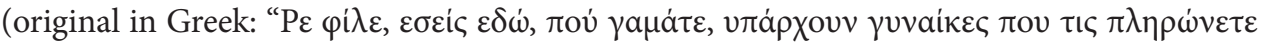

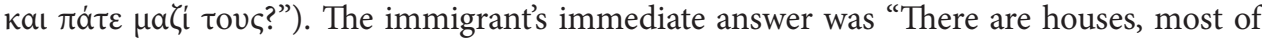
them in the fields, that have women and with $£ 20$ we get laid" (original in Greek: "Yrópxouv

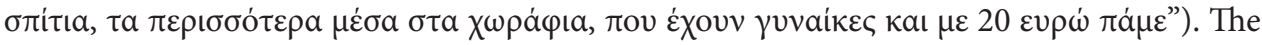
immigrant continues to describe the conditions of women's forced sex labour, and states that the women were from around the entire globe. These women were not given any specific names or nationalities in the article, and they are represented in Caryatid Unplugged by the fictional character XX. The character is named after the gender chromosome type for females $\mathrm{XX}$. XX speaks about the conditions of her forced sex labour as witnessed by the male illegal immigrant. The fact that the character Salim has a name and nationality, whereas XX has neither, highlights the advanced vulnerability of the female body in Manolada's shooting story. The male immigrants were shot by the landowners. The incident attracted the attention of both the media and the authorities concerning the abuse of the male immigrants. This attention led not only to the pursuit of justice but also to the identification of the men and their nationalities. The female immigrants were abused by both human traffickers and trafficked male workers. Their story has not been further investigated and therefore not only have they been denied justice but also identification. The lack of identity becomes synonymous with the violation of the women's human rights. @MPOUZOUKAKI, "Where Do the 8000 Refugees

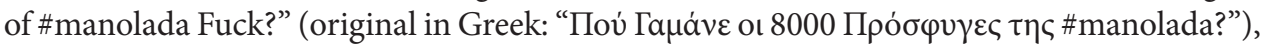
Omnia TV, May 12, 2013. To view full article, go to https://omniatv.com/blog/3022-rov-

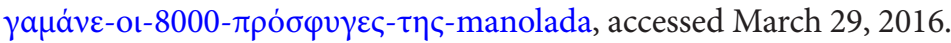

19 Pierre Bourdieu, "The Economics of Linguistic Exchanges," Social Science Information 16, no. 6 (1977): 645-68.

20 Pulp, "Common People," on Different Class (UK: Island Records, October 30, 1995), CD. To view website with full lyrics, go to http://www.lyricsmode.com/lyrics/p/pulp/common_ people.html, accessed February 16, 2016.

21 Evi Stamatiou, "Caryatid Unplugged" (unpublished, 2013), 5.

22 The musical number is from the musical Sweet Charity, which was created in 1966 with music by Cy Coleman, lyrics by Dorothy Fields, book by Neil Simon, and direction and choreography by Bob Fosse. In 1969 the stage musical was adapted to a film musical with 
screenplay by Peter Stone, direction and choreography by Bob Fosse, and production by Robert Arthur for Universal Pictures.

23 The musical Sweet Charity played a major role in the construction of my cosmopolitan identity. The African American and Caribbean movement influences in Bob Fosse's choreography challenged the orderly aesthetics of my classical training in ballet and piano. The influence of Federico Fellini's film Nights in Cabiria (1959) on the story of the musical further revealed the merging of multicultural influences in the creation of Sweet Charity. My taste in dance was challenged, and I left the ballet classes for modern jazz classes: my attempt to reach out to non-European dance was opening possibilities for my cosmopolitan identity.

24 Dorothy Fields, "Big Spender," in Sweet Charity, book by Neil Simon and music by Cy Coleman, New York, 1966. To view the lyrics, go to http://www.stlyrics.com/lyrics/ sweetcharity/bigspender.htm, accessed April 11, 2016.

25 Stamatiou, "Caryatid Unplugged," 14.

26 Helen Gilbert and Jacqueline Lo, Performance and Cosmopolitics: Cross-cultural Transactions in Australasia (UK: Palgrave Macmillan, 2007), 87.

27 Ibid., 10-12.

28 Stamatiou, "Caryatid Unplugged," 15.

29 Salim's true story is that he was an immigrant worker in greenhouses in Crete, and he described similar working conditions to the ones in Manolada in Frangisca Megaloudis' article "Life in 'Cretan Manolada" (see n. 17). The only dissimilarity to the conditions in Manolada is that Salim wasn't shot by the landowners. For the purposes of "Caryatid Unplugged," Salim's story has been merged with stories emerging from Manolada. An indicative article can be found in BBC News article "Greece Farm Shooting: 30 Injured in Pay Dispute," BBC News, April 18, 2013. To view full article, go to http://www.bbc.co.uk/ news/world-europe-22198699, accessed March 29, 2016.

30 Stamatiou, "Caryatid Unplugged," 18. The article's title within the quote is from source Omnia TV, 2013 (see n. 18).

31 Nick Awde, "Caryatid Unplugged," review, Theatre London Guide, August 14, 2013. To view full review, go to http://www.theatreguidelondon.co.uk/reviews/edinburgh2013-1.htm, and scroll down to "Caryatid Unplugged", accessed April 11, 2016.

32 To view video online of "My John, Your Handkerchief” (1950), go to http://www.greeksongsgreekmusic.com/gianni-mou-to-mantili-sou-glikeria/, accessed April 11, 2016.

33 Ibid.

34 In the original song, the verse is repeated anyway, and one would expect that the translator's inability to understand the first verse would have a comedic effect for Greek audiences, who would be familiar with the song and its repetition of verses.

35 Stamatiou, "Caryatid Unplugged," 22.

36 Ibid., 27.

37 Armand D’Angour, "How Did Ancient Greek Music Sound?” BBC News, October 23, 2016. To view full article, go to http://www.bbc.co.uk/news/business-24611454, accessed February 20, 2016.

38 The Pontic Greeks were a population that lived around Caucasus and the Black Sea until 1922. The Greek population of the Pontos before World War I was approximately 700,000 
(Valavanis, 15). By 1924, about 353,000 had perished (Ibid., 24). The remainder followed the road of the diaspora, mainly to Greece and the Soviet Union, but also to America, the rest of Europe, and Persia (Ibid.). Georgios Valavanis, Modern General History of the Pontos, $2^{\text {nd }}$ ed. (Thessaloniki: Kiriakidis Bros., 1986).

39 Jürgen Habermas, The Structural Transformation of the Public Sphere: An Inquiry into a Category of Bourgeois Society, $10^{\text {th }}$ ed., Studies in Contemporary German Social Thought (Cambridge: MIT Press, 1999), 221.

40 Craig Calhoun ed., introduction to Habermas and the Public Sphere, Studies in Contemporary German Social Thought (Cambridge: MIT Press, 2011), 6.

41 Ibid.

42 Chantal Mouffe, The Democratic Paradox (London and New York: Verso, 2000), 3.

43 Watts, "David Cameron, 'Prepared to Halt Immigration of Greeks into UK," 2012.

44 Mouffe, The Democratic Paradox, 13.

45 Ibid.

46 Ibid., 16.

47 Helen Freshwater, Theatre and Audience (Palgrave Macmillan, 2009), 5.

48 Stamatiou, "Caryatid Unplugged," 14. The reference to the film director Pier Paolo Pasolini serves the comic effect. His relation to Ancient Greek culture is his film Edipo Re (1967), which is an adaptation of Sophocles' Oedipus Tyrannus (430 вс).

49 Greek phonetic for "thank you."

50 Greek phonetic for "good evening."

51 Bourdieu, Language and Symbolic Power, 45.

52 Stamatiou, "Caryatid Unplugged," 22

53 Gilbert and Lo, Performance and Cosmopolitics, 87.

54 Mikhail Bakhtin, "The Prehistory of Novelistic Discourse," in Modern Criticism and Theory: A Reader, ed. David Lodge (New York: Longman, 1988), 126. 